\title{
Het nieuwe werken en kennisdelen: de rol van organisatie-identificatie en autonomie *
}

\author{
Rick van der Kleij, Merle Blok, Olav Aarts, Pepijn Vos \& Livia Weyers ${ }^{* *}$
}

\begin{abstract}
Het Nieuwe Werken (HNW) is een manier van werken en samenwerken, veelal ondersteund door technologie, gericht op het verbeteren van de productiviteit, werkplezier, werk-privé-balans, concurrentievermogen en het reduceren van de milieudruk. HNW lijkt vooral geschikt voor kennisintensieve organisaties en kenniswerkers. Er is echter nog nauwelijks onderzoek gedaan naar de effecten van HNW op kennisdelen. Het weinige kwantitatieve onderzoek naar HNW laat bovendien dubbelzinnige resultaten zien. Deze studie kijkt naar de relatie tussen HNW en kennisdelen van medewerkers van een kennisintensieve organisatie. Onze verwachting is dat kennisdelen toeneemt door specifieke karakteristieken van HNW: een toename in het gebruik van ICT, zoals videoconferencing, en een grotere flexibiliteit in het gebruik van werkplekfaciliteiten, bijvoorbeeld door ingebruikname van flexwerkplekken en ontmoetingsruimtes. De ICT biedt mogelijkheden om plaats- en tijdonafhankelijk kennis te delen. Flexibiliteit van werkplekfaciliteiten kan leiden tot een verhoging van spontane en informele ontmoetingen. Bovendien is de verwachting dat organisatie-identificatie en autonomie de relatie tussen HNW en kennisdeling grotendeels verklaren. Regressieanalyse op vragenlijstdata van 712 individuen, verzameld bij een grote Nederlandse IT-dienstverlener waar recentelijk $H N W$-maatregelen zijn ingevoerd, bevestigt deels onze hypotheses.
\end{abstract}

\section{Inleiding}

De Nederlandse economie is op een aantal punten fundamenteel aan het veranderen. Organisaties moeten steeds efficiënter produceren, vooral als het Nederlandse bedrijfsleven haar toppositie op de ranglijst van meest concurrerende economieën wil blijven verdedigen (Coevert, 2012). In de komende jaren gaan we in Nederland te maken krijgen met een drastisch krimpende arbeidsmarkt en steeds grotere opschuiving richting kenniseconomie. Bedrijven moeten steeds sneller kunnen inspelen op de veranderde behoeften van klanten en werknemers. De huidige werkomgeving en werkprocessen van veel werknemers voldoen al lang niet meer aan de eisen die het werk stelt en vragen om verandering. De eerste ver-

* De auteurs zijn Christiaan van den Berg van TNO en KPN Corporate Market dankbaar voor hun bijdrage aan dit onderzoek.

** Rick van der Kleij is werkzaam bij TNO, Behavioural and Societal Sciences, e-mailadres: Rick.vanderKleij@tno.nl. Merle Blok is werkzaam bij TNO, Behavioural and Societal Sciences. Olav Aarts is werkzaam bij TNO, Behavioural and Societal Sciences. Pepijn Vos is werkzaam bij TNO, Behavioural and Societal Sciences. Livia Weyers was tijdens dit onderzoek als afstudeerder verbonden aan de Universiteit Utrecht. 
anderingen zijn al zichtbaar bij enkele beeldbepalende bedrijven en worden geschaard onder de term: Het Nieuwe Werken (HNW).

HNW is een manier van werken waarbij de werknemer op verschillende werklocaties en -ruimtes werkt en gebruikmaakt van ICT-faciliteiten om plaats- en tijdonafhankelijk te werken. Niet elk werk kan plaats- en tijdonafhankelijk worden gedaan. Het handwerk in fabrieken of op de bouwplaats leent zich minder goed voor plaats- en tijdonafhankelijk werken. In deze studie richten we ons dan ook vooral op kenniswerkers: het deel van de werkende bevolking dat voornamelijk met hun hoofd en met informatie werken (Bijl, 2009). Kenniswerkers werken veelal in kennisintensieve organisaties: een organisatie waarin de productiefactor kennis een dominante rol heeft (Weggeman, 1997). Kennis is datgene wat mensen in staat stelt vanuit hun doelen betekenis toe te kennen aan gegevens (Van der Spek \& Spijkervet, 1996). Daarmee worden gegevens omgezet in informatie. Kennis is het geheel van inzichten, ervaringen, procedures die voor juist worden gehouden en daarmee richting geven aan het denken, handelen en communiceren van mensen. Kennis is in meerdere situaties en over een relatief lange periode toepasbaar. Voor kennisintensieve organisaties lijkt het overgaan op HNW een kans om zowel de prestaties en de bevlogenheid van medewerkers te verhogen, als de kosten voor faciliteiten te reduceren, terwijl tegelijkertijd de positie als aantrekkelijke werkgever en het aanpassingsvermogen van de organisatie toeneemt. Technologische innovaties zijn belangrijke aanjagers van HNW. Hierbij kan men denken aan technologieën als videoconferencing, smartphones en laptops. Deze technologieën ondersteunen virtueel samenwerken tussen organisatieleden die verschillende werktijden hebben of op verschillende vestigingen van dezelfde organisatie werken (Van der Kleij \& Schraagen, 2006; Van der Kleij et al., 2009). Technologische innovaties ondersteunen bovendien het verkrijgen van toegang tot bedrijfsinformatie vanuit verschillende locaties (bijvoorbeeld onderweg, thuis en bij klanten). Het kantoor is niet langer de plek om te werken, maar wordt in toenemende mate een ontmoetingsplek (Vink, 2009; Vink et al., 2011). Dit maakt het voor bedrijven mogelijk om te besparen op reiskosten en het aantal vierkante meter fysieke werkruimte. Dit wordt ondersteund door thuiswerkregelingen, flexibele werkplekken, activiteit gerelateerd werken en flexibele werktijden (Blok et al., 2011). Er is echter nog weinig evidentie voor de effecten van HNW op een belangrijke bedrijfsdoelstelling van kennisintensieve organisaties; namelijk de productie van kennis. Ook mogelijke relaties tussen HNW en andere bedrijfsdoelen, zoals productiviteit, innovaties, klantwaarde, werknemersbevlogenheid en de samenwerking binnen en tussen bedrijfsonderdelen zijn nog nauwelijks onderzocht (Blok et al., 2011; Butler et al., 2007; Habets, 2009; Gajendran \& Harrison 2007; Golden, 2006; Venkatesch \& Speier, 2000; Wermenbol, 2008). Dit onderzoek richt zich op de vraag: In welke mate is er een relatie tussen HNW en kennisdelen van werknemers binnen kennisintensieve organisaties?

Kennis is essentieel voor het succesvol ondernemen van kennisintensieve organisaties. Quinn et al. (1996) vonden dat de waarde van de productiefactor kennis groeit wanneer deze wordt gedeeld. Als er kennis wordt gedeeld, dan levert dit voordeel op voor de ontvangers van de informatie. Het delen van kennis helpt de individuele medewerkers namelijk met het doen van hun werk: door te leren van 
anderen kan het werk sneller, beter en met minder fouten worden gerealiseerd (Van der Kleij et al., 2008). Er worden bovendien verbeteringen en aanpassingen gedaan aan de originele informatie, waardoor er waarde wordt toegevoegd aan het originele bericht (Quinn et al., 1996). Het delen van kennis ondersteunt daarmee de ontwikkeling van individuele vaardigheden, het leervermogen én het innovatieve vermogen van de organisatie.

Onze verwachting is dat HNW leidt tot meer uitwisseling van kennis (zie ook Hendriks, 1999). HNW betekent vaak dat er een toename is in (1) het aanbod van Informatie- en Communicatietechnologie (ICT) en (2) werkplekfaciliteiten. ICT biedt mogelijkheden om makkelijker plaats- en tijdonafhankelijk samen te werken. Een grotere mobiliteit met betrekking tot de werkplek kan leiden tot een toename in het delen van kennis door de verhoging van spontane en informele ontmoetingen met mensen binnen en buiten het werkterrein van de eigen organisatie (zie ook Kiesler \& Cummings, 2002; Kraut et al., 2002). In deze studie zijn de effecten onderzocht van de hierboven vermelde twee aspecten van HNW op kennisdelen, namelijk (1) de mate waarin werknemers gebruik kunnen maken van ICT om plaats- en tijdonafhankelijk te werken, en (2) werkplek-gerelateerde faciliteiten om flexibel te werken. Deze studie kijkt ook naar de rol van ervaren autonomie van de medewerker en identificatie met het bedrijf in het verklaren van de mogelijke relatie tussen HNW en kennisdelen.

\section{Het Nieuwe Werken}

HNW wordt regelmatig verward met telewerken. Shin et al. (2000) definiëren telewerken als werk dat thuis of in een satellietkantoor, een kantoorruimte waar in de buurt wonende of passerende mobiele werkers terecht kunnen, wordt uitgevoerd om het woon-werkverkeer te reduceren. Illegems en Verbeke (2004) breiden deze definitie uit door te stellen dat telewerken betaald werk is dat - minimaal een dag per werkweek - thuis, in een satellietkantoor, of op iedere andere werkplek buiten het kantoor om wordt uitgevoerd.

De literatuur noemt diverse voor- en nadelen van telewerken (Harpaz, 2002). Gajendran en Harrison (2007) vonden enkele kleine, maar positieve effecten van telewerken: werknemers ervoeren meer autonomie en rapporteerden minder werk-thuis conflicten. Gajendran en Harrison (2007) vonden bovendien een positief effect van telewerken op werktevredenheid, prestatie en ziekteverzuim. Aan de andere kant resulteerde langdurig telewerken (meer dan 2,5 dag per week) in een beschadiging van de relaties met collega's. Uit onderzoek van Kurland en Cooper (2002) en Richardson (2010) blijkt dat telewerkers in een isolement raken omdat ze het gevoel hebben dat ze weinig contact hebben met collega's en carrièremogelijkheden mislopen. Kamerade en Burchell (2004) vonden echter dat telewerkers meer vrijwillig deelnemen aan sociale activiteiten dan niet-telewerkers. $\mathrm{Zij}$ concluderen dat telewerken kan worden beschouwd als een gemeenschapsvriendelijke vorm van werken.

Binnen bovenstaande definities van telewerken draait het echter grotendeels om het thuiswerken. Bij HNW staat het thuiswerken niet centraal. HNW heeft als doel om werken effectiever en efficiënter, maar ook plezieriger te maken voor zowel de organisatie als de medewerker waardoor er een win-win situatie ontstaat 
(Bijl, 2009). Algemeen is de verwachting dat deze 'nieuwe' manier van werken beter aansluit bij de behoefte van de kenniswerker en beter past bij de eisen die het kenniswerk stelt om tot een goed resultaat te komen. Dit gaat ook om het creeren van een productieve, duurzame, inspirerende en teamprestatie bevorderende werkomgeving.

In het kader van HNW worden vaak maatregelen genomen om de autonomie van de werknemer te vergroten in combinatie met het bieden van de mogelijkheid om plaats- en tijdonafhankelijk te kunnen werken. Voorbeelden van HNW-maatregelen zijn: het herinrichten van werklocaties-/ ruimtes (bijvoorbeeld meer flexwerkplekken, ontmoetingsruimtes, thuisfaciliteiten), het veranderen van het aanbod in ICT-faciliteiten (bijvoorbeeld smartphones, laptops), het implementeren van nieuwe HR-beleidskaders (bijvoorbeeld stimuleren om thuis te werken en op flexibele tijden te werken) en het veranderen in de manier van aansturen (bijvoorbeeld meer gericht op resultaat in plaats van aanwezigheid). In deze studie richten we ons specifiek op het herinrichten van werklocaties-/ ruimtes en het veranderen van het aanbod in ICT-faciliteiten. De overige aspecten van HNW blijven buiten beschouwing.

\section{Kennisdelen}

Voor organisaties is het van belang dat medewerkers kennis delen. Door kennisuitwisseling kan een optimale prestatie worden behaald en een voordeel worden verkregen ten opzichte van concurrerende organisaties (Argote \& Ingram, 2000; Huang, 2009; Yuan, 2010). Bartol en Srivastava (2002) omschrijven kennis als informatie, ideeën en expertise die relevant zijn voor de taken die moeten worden uitgevoerd door individuen, teams, werkeenheden en organisaties in het geheel. Wij definiëren kennisdelen als de uitwisseling van relevante informatie, ideeën en expertise tussen medewerkers (zie ook Bartol \& Srivastava, 2002; Usoro et al., 2007).

Tsai (2002) laat zien dat een formele hiërarchische structuur, in de vorm van centralisatie, een negatief effect heeft op kennisdeling. Hij stelt dat afdelingen in sterk gecentraliseerde organisaties niet geïnteresseerd zijn in het delen van kennis met andere afdelingen tenzij dit wordt geëist door een hogere autoriteit. Deze inactieve rol reduceert de mogelijkheid om een voordelige kennisstroom te creëren (Tsai, 2002). Informele en zijdelingse betrekkingen hebben echter een significant positief effect op kennisdeling tussen afdelingen. Wij verwachten dat werkplek-gerelateerde faciliteiten om flexibel te werken de vorming van informele en zijdelingse betrekkingen ondersteunt. Medewerkers krijgen meer vrijheid in het bepalen van hun werkplek, waardoor kansen ontstaan voor nieuwe, informele contacten en ad hoc ontmoetingen.

Ook het gebruik van ICT kan bijdragen aan een verhoogde mate van kennisdelen binnen organisaties. ICT stelt organisaties in staat om tijdelijke en ruimtelijke barrières tussen kenniswerkers te verlagen (Gorton \& Motwani, 1996; Gupta et al., 2009; Hendriks, 1999; Hinds \& Bailey, 2003; Rico \& Cohen, 2005). ICT ondersteunt bovendien verbeterde toegang tot informatie en collega's die kennis bezitten. Bijvoorbeeld, het gebruik van Smartphones stelt medewerkers in staat om ook onderweg en thuis ideeën uit te wisselen met collega's, bijvoorbeeld via sms, 
mail of sociale-media-achtige applicaties als Twitter, Yammer en Messenger. Volgens deze redenering is er een verband tussen de mate waarin medewerkers kennisdelen en de moeite die het hun kost om afnemers van die kennis te vinden. De oplossing van dit probleem is om deze moeite significant te verminderen, bijvoorbeeld door het ontwikkelen van intranettoepassingen voor het zoeken van expertises binnen het bedrijf.

Op basis van de verwachtingen die in vorige secties zijn genoemd, kan de volgende hypothese worden opgesteld:

Hypothese 1: Er is een positieve relatie tussen de mate waarin HNW in kennisintensieve organisaties is doorgevoerd en de mate van kennisdelen tussen medewerkers onderling.

In het vervolg van dit artikel bespreken we twee aspecten die de relatie tussen HNW en kennisdelen (deels) kunnen verklaren: organisatie-identificatie en autonomie van medewerkers.

\section{Organisatie-identificatie}

Gebaseerd op de sociale-identiteit-theorie van Ashforth en Mael (1989) definieren Mael en Ashforth (1992) organisatie-identificatie als de perceptie van iemand ten opzichte van diens verbondenheid met een organisatie, waarbij een individu met een grote organisatie-identificatie zichzelf sterk identificeert met de organisatie waarvan hij/zij lid is. Sociale identificatie treedt op als iemand zichzelf als onderdeel van een bepaalde groep beschouwt. Vanuit dit perspectief gezien stellen Mael en Ashforth dat organisatie-identificatie kan worden gezien als een speciale vorm van sociale identificatie waarbij het individu zichzelf definieert via het lidmaatschap van een specifieke organisatie.

Door de mogelijkheden van plaats- en tijdonafhankelijk werken te stimuleren zal het vaker voorkomen dat werknemers zich op een andere plek dan de eigen organisatie bevinden. Hobbs en Armstrong (1998), Kurland en Cooper (2002) en Wiesenfeld et al. (2001) vonden dat virtueel werk, waarbij werknemers op een andere locatie dan op kantoor werken, de isolatie en afhankelijkheid van werknemers vergroot. Wiesenfeld et al. (2001) geven het belang van organisatie-identificatie bij virtueel werk aan: organisatie-identificatie kan het verlies van de aspecten van de traditionele organisatie, die samenwerking, coördinatie en lange-termijninspanningen van werknemers faciliteert, vervangen of compenseren. Een hoge mate van organisatie-identificatie is van belang omdat dit positieve effecten kan hebben op de mate waarin mensen gemotiveerd zijn om coöperatief gedrag te vertonen in het belang van de organisatie en beslissingen te nemen die in overeenstemming zijn met de doelen van de organisatie (Dutton et al., 1994; Mael \& Ashforth, 1995).

Ondanks het feit dat plaats- en tijdonafhankelijk werk de isolatie en afhankelijkheid van werknemers kan vergroten, verwachten wij dat organisatie-identificatie als gevolg van de invoering van HNW zal toenemen. Deze verwachting is in lijn met voorgaand onderzoek dat uitwees dat werknemers, ook al voelen zij zich geïsoleerd van de organisatie, zich nog steeds sterk kunnen identificeren met het 
bedrijf (Brewer, 1979; Fiol \& O’Connor, 2005). Wiesenfeld et al. (2001) stellen dat informele elektronische communicatie een belangrijke rol kan spelen bij deze ogenschijnlijke tegenstrijdigheid. E-mail en telefoon maken collega's toegankelijk ongeacht de locatie waar zij zich bevinden en vereenvoudigen het starten van informele communicatie. Communicatietechnologie helpt leden van de organisatie in het proces van het creëren en delen van de organisatie-identiteit. De laatste jaren is het aantal manieren van elektronische communicatie toegenomen. Wij verwachten dan ook dat het invoeren van ICT-faciliteiten om plaats- en tijdonafhankelijk te werken zal zorgen voor een toename van opties van informeel, elektronisch communiceren binnen bedrijven. Hierdoor zal ook de identificatie met het bedrijf toenemen.

Als we kijken naar de relatie tussen organisatie-identificatie en kennisdelen, zien we dat uit onderzoek van Polzer (2004) blijkt dat een hogere mate van organisatie-identificatie leidt tot een lagere samenwerking met het collectieve en een hogere samenwerking met de subgroep. Dit was vooral het geval wanneer de andere groep een individualistische instelling had. Volgens Brewer (1981) hebben mensen de neiging om een positieve bias te hebben tegen leden van hun eigen groep, de in-groep, door ze als relatief betrouwbaar, eerlijk en meewerkend te beschouwen, wat resulteert in een groep-gebaseerd vertrouwen in tegenstelling tot het alleen kunnen vertrouwen op jezelf. Vertrouwen dat is gebaseerd op groepsidentificatie, ondersteunt de samenwerking, omdat - zonder deze identificatie - bij de groepsleden de angst kan ontstaan dat, zodra er een gunst wordt verleend aan een groepsgenoot, deze niet wordt beantwoord. Groepsidentificatie vermindert deze angst voor exploitatie door groepsleden, waardoor samenwerking en kennisdelen worden bevorderd. ICT-maatregelen op het gebied van HNW kunnen informele communicatie bewerkstelligen door het verlagen van de drempel tot communiceren. Bovendien zorgen HNW-maatregelen zoals het herinrichten van werklocaties/-ruimtes ervoor dat werknemers van verschillende afdelingen makkelijker met elkaar in contact kunnen komen. Wij verwachten dan ook een positieve relatie tussen organisatie-identificatie en kennisdelen:

Hypothese 2a: Er is een positieve relatie tussen de mate waarin HNW in kennisintensieve organisaties is doorgevoerd en de mate van organisatie-identificatie van de medewerkers.

Hypothese 2b: Organisatie-identificatie is positief gerelateerd aan kennisdelen.

Hypothese 3: De positieve relatie tussen HNW en kennisdelen wordt (deels) verklaard door organisatie-identificatie.

\section{Autonomie}

Hackman en Oldham (1975) en Turner en Lawrence (1965) definiëren autonomie als 'de mate waarin het werk substantiële vrijheid, onafhankelijkheid en discretie verschaft aan het individu bij het indelen van het werk en bij het beslissen op welke manier het werk wordt uitgevoerd'. Breaugh (1985) breidt deze definitie uit door te stellen dat autonomie meerdere dimensies heeft (zie ook Evans \& Fischer, 1992). In zijn onderzoek heeft hij een instrument ontwikkeld, waarin hij autonomie op een valide manier verdeelt in drie aspecten: werkmethode-autonomie (de 
mate waarin werknemers kunnen kiezen welke procedures/methodes ze gebruiken bij het uitvoeren van hun taken), werkindeling-autonomie (de mate waarin werknemers het gevoel hebben dat ze controle hebben over de indeling/volgorde/ tijdsplanning van hun taken) en werkcriteria-autonomie (de mate waarin werknemers de mogelijkheid hebben om de criteria die gebruikt worden voor het evalueren van hun functioneren aan te passen of te kiezen).

Medewerkers van een organisatie waar HNW is ingevoerd, hebben veelal ook de mogelijkheid om zelf te bepalen waar, wanneer en met welke middelen zij werken (Elsbach, 2003; Standen, 2000). Wij verwachten dat deze toegenomen zelfstandigheid en flexibiliteit de mate van autonomie doet toenemen. Gezien de vrijheid om zelf te bepalen waar, wanneer en met welke middelen er wordt gewerkt, is autonomie in deze studie toegespitst op de werkindeling-autonomie. Langfred (2004) en Orton en Weick (1990) stellen dat hoe meer individuele autonomie aanwezig is in een team, hoe meer de teamleden onafhankelijk van elkaar gaan werken. Dit betekent dat er meer behoefte is monitoring en communicatie om potentieel verlies van coördinatie en het proces te vermijden. Toch vonden Cabrera et al. (2006) dat autonomie gerelateerd is aan een hoog niveau van kennisdeling. Uit hun studie blijkt dat werkautonomie verbonden is aan een gevoel van verantwoordelijkheid dat zal leiden tot een zoektocht naar meer efficiënte manieren om het werk uit te voeren. Een van de manieren om efficiënter te werken is om ideeën en ervaringen te delen met andere werknemers. Het gebrek aan precieze instructies en procedures hoe het werk moet worden uitgevoerd, kan leiden tot meer kennisdeling, aangezien werknemers het nut meer inzien van het zoeken naar een nieuwe en creatieve manier om het werk uit te voeren.

Op basis van de hierboven besproken literatuur verwachten wij dat:

Hypothese 4a: Er is een positieve relatie tussen de mate waarin HNW in organisaties is doorgevoerd en de mate van ervaren werkindeling-autonomie van de medewerkers.

Hypothese 4b: Werkindeling-autonomie is positief gerelateerd aan kennisdelen.

Hypothese 5: De positieve relatie tussen HNW en kennisdelen wordt (deels) verklaard door ervaren werkindeling-autonomie.

Figuur 1 geeft een samenvatting van onze verwachtingen en analyse tot nu toe in een paddiagram. Het paddiagram illustreert de veronderstelde relatie tussen de vier variabelen in deze studie. De invoering van HNW heeft drie gerelateerde effecten. Ten eerste verwachten wij een effect van HNW op de mate van kennisdelen binnen organisaties. Ten tweede heeft de invoering van HNW een effect op de ervaren autonomie van medewerkers. En ten derde heeft HNW een effect op de mate van organisatie-identificatie van de medewerkers. Bovendien verwachten wij dat de mate van autonomie en organisatie-identificatie de relatie tussen HNW en kennisdelen gedeeltelijk medieert. 
Figuur 1 De rol van organisatie-identificatie en autonomie op de relatie tussen HNW en kennisdelen in kennisintensieve organisaties

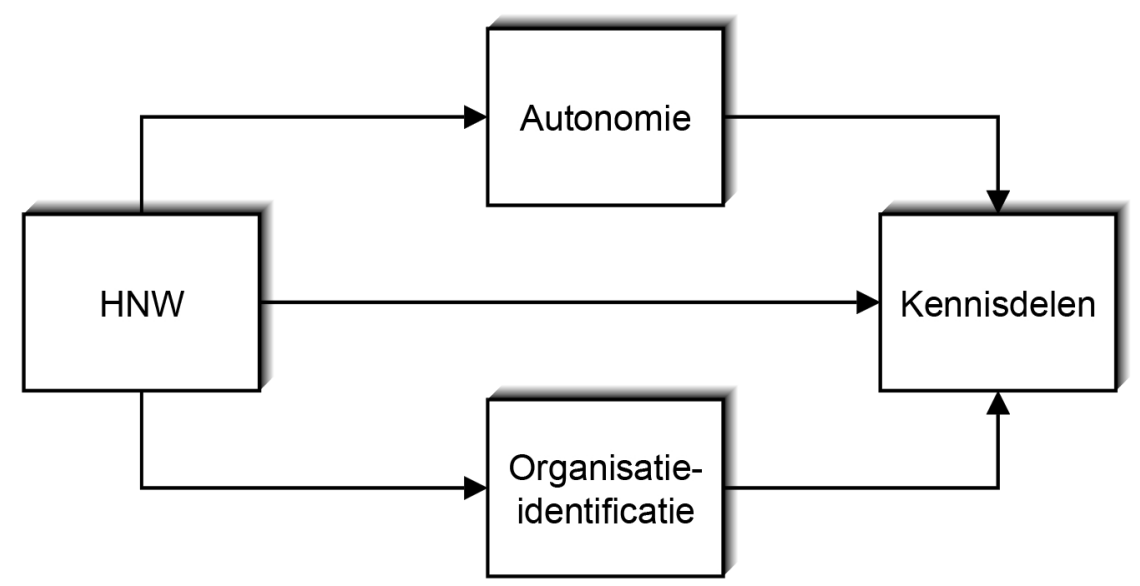

\section{Methoden}

Steekproef en procedure

Om de hypotheses te toetsen zijn data verzameld bij werknemers van KPN Corporate Market (voorheen Getronics Nederland BV), een grote Nederlandse ICTdienstverlener waar recentelijk HNW-maatregelen zijn ingevoerd. In totaal hebben 1.075 personen de link naar de digitale vragenlijst geopend. 712 mensen hebben de vragenlijst volledig ingevuld (66,2\%). De steekproef bestond uit 113 vrouwen (15,9\%) en 599 mannen (84,1\%). De gemiddelde leeftijd was 44,8 jaar (st. dev. $=8,5$ ). Het grootste deel van de respondenten is mbo $(26,3 \%)$, hbo $(43,1 \%)$ of wo $(14,9 \%)$ geschoold. Het merendeel van de deelnemers werkt meer dan 40 uur $(58,1 \%)$ of 37 tot 40 uur $(30,8 \%)$ per week.

De deelnemers zijn door het management van KPN collectief benaderd om mee te werken aan dit onderzoek. Aan KPN is gevraagd de vragenlijst alleen uit te zetten onder afdelingen met 'kenniswerkers'. We hebben hiervoor echter niet achteraf gecontroleerd. We kunnen dus niet uitsluiten dat hier en daar ook ondersteunend personeel of uitvoerend personeel (handwerkers) heeft meegedaan aan het onderzoek.

De vragenlijst bestond uit verschillende items waaruit later diverse schalen geconstrueerd zijn. Uit betrouwbaarheidsanalyses bleek dat de Cronbach's $\alpha$ van twee van de schalen lag tussen de 0,6 en 0,7. Ondanks de lage interne consistentie van de items op de bovenliggende constructen is besloten de schalen intact te laten en op constructniveau te analyseren. In totaal bestond de vragenlijst uit 138 vragen, waarvan 10 open en 128 meerkeuzevragen. Voor dit onderzoek is gebruikgemaakt van cross-sectionele data, afkomstig uit 36 vragen, waarvan 2 open (leeftijd en werkervaring) en 34 meerkeuzevragen. 


\section{Meetinstrumenten}

Het Nieuwe Werken (HNW). Onder de paraplu van HNW kunnen diverse soorten maatregelen worden ingevoerd binnen organisaties. In deze studie hebben we ons beperkt tot de fysieke werkplekaspecten en ICT-aspecten (zie ook Baan, 2006; Wermenbol, 2008). Met fysieke werkplekaspecten bedoelen we de mate waarin werknemers gebruik kunnen maken van werkplek-gerelateerde faciliteiten om flexibel te werken, zoals flexplekken en ontmoetingsruimtes. Met ICT-aspecten bedoelen we de mate waarin werknemers gebruik kunnen maken van ICT om plaats- en tijdonafhankelijk te werken. Deze maatregelen vallen vooral onder de noemer van voorzieningen, waaronder infrastructuur. Andersoortige maatregelen, zoals financieel-economische prikkels, waaronder subsidies en heffingen, voorlichting, en voorschriften, waaronder wet- en regelgeving, worden in deze studie dus buiten beschouwing gelaten.

Het gebruik van ICT-faciliteiten is gemeten met 4 items $(\alpha=, 67)$. Voorbeeldvragen zijn: 'Geef aan hoeveel \% van uw totale werktijd u voor uw werk gebruikmaakt van video- en/of teleconferencing' en 'Geef aan hoeveel \% van uw totale werktijd u voor uw werk gebruikmaakt van collaborative tools, zoals SharePoint of OneNote'. De items zijn gescoord op een 6 -puntsschaal, waarbij $0=0 \%$ en $5=81-100 \%$. De schaalscores hadden een range van 0 tot 4,25.

Het gebruik van werkplekfaciliteiten is gemeten met 12 items $(\alpha=, 71)$. Voorbeeldvragen zijn: 'In de afgelopen 4 weken werkte ik per week gemiddeld genomen ..\% thuis', 'In de afgelopen 4 weken maakte ik per week gemiddeld genomen ..\% gebruik van brainstorm-/creativiteitsruimtes' en 'In de afgelopen 4 weken maakte ik per week gemiddeld genomen ..\% gebruik van flexwerkplekken'. De items zijn gescoord op een 6 -puntsschaal, waarbij $0=0 \%$ en $5=81-100 \%$. De range van de schaalscores was 0 tot 2,75 .

Kennisdelen. Kennisdelen binnen de organisatie is gemeten met 3 items $(\alpha=.66)$. De schaal is gebaseerd op de TNO Werk Energie Meter en de Team Member Proficiency-schaal van Griffin et al. (2007). Een voorbeeldvraag is: 'Wij besteden in de organisatie aandacht aan het goed gebruiken van elkaars kwaliteiten en kennis.' De items zijn gescoord op een 5 -punts Likertschaal, waarbij 0 = zeer mee oneens en 4 = zeer mee eens.

Organisatie-identificatie. Organisatie-identificatie is gemeten met behulp van 5 items $(\alpha=.79)$, gebaseerd op Mael en Ashforth (1992). Voorbeelditems zijn: 'Ik voel mij sterk verbonden met de organisatie' en 'Wanneer ik vertel over mijn organisatie, refereer ik vaak naar "wij" in plaats van "ik". Alle items zijn gescoord op een 5punts Likertschaal, waarbij 0 = zeer mee oneens en $4=$ zeer mee eens.

Autonomie. Autonomie is gemeten met behulp van de Work Scheduling Autonomyschaal, een subschaal van de door Morgeson en Humphrey (2006) ontwikkelde Work Design Questionnaire. Autonomie wordt gemeten met 4 items $(\alpha=.85)$ en meet in hoeverre werknemers autonoom zijn in de planning van hun werk, met als voorbeelditems: 'Ik bepaal zelf de volgorde van mijn werkzaamheden' en 'Ik kan zelf beslissen hoe ik mijn werk uitvoer'. De items zijn gescoord op een 5-punts Likertschaal, waarbij 0 = zeer mee oneens en $4=$ zeer mee eens. 
Tabel 1 Gemiddelde, standaarddeviatie en Pearson's correlatiecoëfficiënten tussen de variabelen $(N=712)$

\begin{tabular}{|c|c|c|c|c|c|c|c|c|}
\hline Variabele & $M$ & SD & I & 2 & 3 & 4 & 5 & 6 \\
\hline I. HNW-ICT & 83 & ,63 & - & & & & & \\
\hline 2. HNW-werkplek & $\mathrm{I}, 07$ &, 57 &, $23 * *$ & - & & & & \\
\hline 3. Kennisdelen & 3,00 &, 56 &, $12 * *$ &,- 02 & - & & & \\
\hline 4. Identificatie & 2,48 & ,67 &, $08 *$ &, $18 * *$ &, $34 * *$ & - & & \\
\hline 5. Autonomie & 2,87 & ,81 &, $16 * *$ &, $42^{* *}$ &, $19 * *$ &, $28 * *$ & - & \\
\hline 6. Ervaring & 15,10 & 10,20 &,$- 23 * *$ &,$- 08^{*}$ &, $14 * *$ &, $10 *$ &, 00 & - \\
\hline 7. Geslacht ${ }^{\mathrm{a}}$ &, 16 & ,37 &,- 02 &,- 04 &,- 06 &,- 03 &,- 00 &,$- 16 * *$ \\
\hline
\end{tabular}

$* p<.05$ (tweezijdig); $* * p<.01$ (tweezijdig)

a $\operatorname{Man}=0$, vrouw $=\mathrm{I}$.

Controlevariabelen. Omdat eerder onderzoek laat zien dat geslacht is gerelateerd aan HNW, is gecontroleerd voor deze variabele. Telewerken komt vaker voor onder mannen, zo blijkt uit de Nationale Enquête Arbeidsomstandigheden, 2010, die uitgezet is onder 21.553 werknemers (TNO \& CBS, 2011).Vrouwen schijnen zich ongemakkelijker te voelen wanneer zij thuis mails of telefoontjes voor hun werk afhandelen (ANP, 2011). Bovendien blijkt dat mannen het belangrijker vinden om plaats- en tijdonafhankelijk te werken (Van Loon, 2011).

Ook is gecontroleerd voor ervaring. Je moet iets 'weten' om het te kunnen delen. Vandaar dat ervaring ook is meegenomen als controlevariabele in deze studie. Ervaring is hier gemeten aan de hand van het aantal jaren dat een medewerker werkzaam is binnen het bedrijf. Hierbij is niet gecorrigeerd voor relevante werkervaring buiten het eigen bedrijf, leeftijd of aantal jaren studie.

\section{Resultaten}

We zijn begonnen met enkele beschrijvende statistieken om meer inzicht te krijgen in de data. Vervolgens is multipele regressieanalyse toegepast om de hypothesen te toetsen. Hierbij zijn verschillende modellen opgesteld om de unieke bijdrage van elk van de variabelen te kunnen onderzoeken. Sobel-testen zijn uitgevoerd om de geïmpliceerde verklaringen van de relatie tussen HNW en kennisdelen te toetsen (zie http://quantpsy.org/sobel/sobel.htm) (Baron \& Kenny, 1986). Een Sobel-test kijkt of een bepaalde variabele de invloed van een onafhankelijke variabele op een afhankelijke variabele draagt.

\section{Beschrijvende statistiek}

Tabel 1 geeft de gemiddelden, standaarddeviaties en de Pearson's correlatiecoëfficiënten tussen de verschillende variabelen weer. Opvallend is dat bijna alle variabelen significant met elkaar correleren. Er is een duidelijk verband tussen HNWICT, ofwel het gebruik van de ICT-faciliteiten binnen de organisatie, en alle andere variabelen. Ook kennisdelen lijkt positief te correleren met alle variabelen 
Tabel 2 Regressieanalyse HNW-ICT, autonomie en organisatie-identificatie voor Kennisdelen

\begin{tabular}{llllll}
\hline Model & $\mathbf{0}$ & $\mathbf{I}$ & $\mathbf{2}$ & $\mathbf{3}$ & $\mathbf{4}$ \\
\hline Intercept & $2,89 * * *$ & $2,74^{* * *}$ & $2,42^{* * *}$ & $2,14^{* * *}$ & $2,02 * * *$ \\
Geslacht (vrouw) &,- 06 &,- 05 &,- 05 &,- 05 &,- 05 \\
Ervaring &, $01 * * *$ &, $01 * * *$ &, $01 * * *$ &, $01 * * *$ &, $01 * * *$ \\
HNW-ICT & &, $15^{* * *}$ &, $12^{* * *}$ &, $12^{* * *}$ &, $10^{* * *}$ \\
Autonomie & & &, $12^{* * *}$ & &, $07 *$ \\
Identificatie & & & &, $26 * * *$ &, $24 * * *$ \\
$\mathrm{R}^{2}$ &, 019 &, 043 &, 070 &, 138 &, 144 \\
Toename $\mathrm{R}^{2}$ & - & $* * *$ & $* * *$ & $* * *$ & $*$ \\
$\mathrm{~N}$ & 712 & & & & \\
$* p<.05 ; * * p<.01 ; * * * p<.001$ & & & &
\end{tabular}

Tabel 3 Regressieanalyse HNW-werkplek, autonomie en organisatieidentificatie voor Kennisdelen

\begin{tabular}{|c|c|c|c|c|c|}
\hline Model & 0 & I & 2 & 3 & 4 \\
\hline Intercept & $2,89 * * *$ & $2,91 * * *$ & $2,55^{* * * *}$ & $2,30 * * *$ & $2,11 * * *$ \\
\hline Geslacht (vrouw) &,- 06 &,- 06 &,- 07 &,- 07 &,- 07 \\
\hline Ervaring &, $01 * * *$ &, $07 * * *$ &, $01 * * *$ &, $01 * *$ &, $01 * *$ \\
\hline HNW-werkplek & &,- 02 &,$- 12^{* *}$ &,$- 08^{*}$ &,$- \mid 14 * * *$ \\
\hline Autonomie & & &, $17 * * *$ & &, $12^{* * *}$ \\
\hline Identificatie & & & &, $28 * * *$ &, $26 * * *$ \\
\hline $\mathrm{R}^{2}$ & 019 & 018 &, 064 & , 128 & , 148 \\
\hline Toename $\mathrm{R}^{2}$ & - & & $* * *$ & $* * *$ & $* * *$ \\
\hline$N$ & 712 & & & & \\
\hline
\end{tabular}

behalve met HNW-werkplek, ofwel het gebruik van flexibele werkplekfaciliteiten binnen de organisatie. Het lage gemiddelde van HNW-ICT kan worden verklaard door het feit dat niet alle ICT-faciliteiten waarnaar is gevraagd, aanwezig waren voor iedereen in de organisatie, zoals mogelijkheden tot gebruik van sociale media, zoals Facebook, Twitter en Yammer.

\section{Toetsende statistiek}

Het effect van de controlevariabele Geslacht is niet significant in alle modellen. We kunnen concluderen dat de gevonden resultaten niet beïnvloed zijn door geslacht. Dit is mogelijk toe te schrijven aan het hoge percentage mannen in de dataset. Tabel 2 geeft de resultaten weer van de regressieanalyse van HNW-ICT, 
Tabel 4 Regressieanalyse HNW-ICT en HNW-werkplek voor autonomie en organisatie-identificatie

\begin{tabular}{|c|c|c|c|c|c|c|}
\hline & Autonomie & Organisatie-identificatie & & & & \\
\hline Model & 0 & $\mathbf{I}$ & 2 & 0 & $\mathbf{I}$ & 2 \\
\hline Intercept & $2,87^{* * * *}$ & $2,70 * * *$ & $2,17 * * *$ & $2,39 * * *$ & $2,27 * * *$ & $2,14 * * *$ \\
\hline Geslacht (vrouw) &,- 01 &,- 01 &, 04 &,- 03 &,- 01 &,- 01 \\
\hline Ervaring &, 00 &, 00 &, 00 &, $01 *$ &, $01 * *$ &, $01 * *$ \\
\hline HNW-ICT & &, $21 * * *$ & & &, $12^{* *}$ & \\
\hline HNW-werkplek & & &, $60 * * *$ & & &, $22 * * *$ \\
\hline $\mathrm{R}^{2}$ &, 000 &, 026 &, 018 &, 009 &, 020 &, 043 \\
\hline$N$ & 712 & & & & & \\
\hline
\end{tabular}

autonomie en identificatie met bedrijf voor kennisdelen. Tabel 3 geeft de resultaten weer van HNW-werkplek, autonomie en identificatie met bedrijf voor kennisdelen. De resultaten van de regressieanalyse met organisatie-identificatie en autonomie als afhankelijke variabelen zijn weergegeven in tabel 4 . Resultaten van de Sobel-test zijn samengevat in tabel 5 .

Zoals te zien is in tabel 2, bestaat er een statistisch significante relatie tussen HNW-ICT en kennisdelen $(\mathrm{t}[708]=3.31, \mathrm{p}<.01)$. HNW-werkplek heeft echter geen statistisch significante relatie met kennisdelen $(\mathrm{t}[708]=-.72, \mathrm{p}=.47$ ) (zie tabel 3). Hypothese 1 kan op basis van deze resultaten deels worden geaccepteerd: er is een positieve relatie tussen de aanwezigheid van HNW-maatregelen in organisaties en de mate van kennisdelen tussen medewerkers onderling, maar alleen wanneer het gebruik van ICT-middelen in ogenschouw wordt genomen. Dit betekent dat alleen de mate waarin werknemers gebruikmaken van ICT om plaats- en tijdonafhankelijk te werken, is gerelateerd aan de mate van kennisdelen in kennisintensieve organisaties. Het gebruik van werkplek-gerelateerde faciliteiten om flexibel te kunnen werken, zoals ontmoetingsruimtes en flexwerkplekken, lijkt in eerste instantie niet te zijn gerelateerd aan kennisdelen. Wanneer organisatie-identificatie en autonomie worden toegevoegd aan het model, wordt de relatie tussen HNW-werkplek en kennisdelen echter wel statistisch significant. Opvallend is dat dit een negatief verband is. Er lijkt sprake te zijn van een suppressie-effect (zie ook Lammers, 1995). In eerste instantie lijkt er geen significante relatie te bestaan tussen HNW-werkplek en kennisdelen. Deze relatie wordt echter gemaskeerd door autonomie en organisatie-identificatie. Autonomie en organisatie-identificatie hebben een positieve invloed op kennisdelen; zou er niet voor deze effecten gecontroleerd worden, dan wordt het effect van HNW-werkplek onderschat. Er is namelijk wel degelijk sprake van een effect van HNW-werkplek op kennisdelen, hetzij een negatieve. Als er geen rekening wordt gehouden met autonomie en organisatie-identificatie, is de relatie tussen HNW-werkplek en kennisdelen vertroebeld en lijkt er geen (negatief) effect van HNW-werkplek op kennisdelen te zijn. Doordat HNW-werkplek positieve effecten heeft op autonomie en organisatie-identificatie, en deze twee op hun beurt weer positieve effec- 
Tabel 5 Sobel-test mediaties tussen HNW-ICT en kennisdeling

\begin{tabular}{lll}
\hline & HNW-ICT & \\
\hline Variabele & Teststatistiek & SE \\
Mediator organisatie-identificatie & $2.74^{* *}$ & 0.01 \\
Mediator autonomie & $3.12^{* *}$ & 0.01 \\
\hline
\end{tabular}

$* p<.05 ; * * p<.01 ; * * * p<.001$

ten hebben op kennisdelen, wordt het negatieve effect van HNW-werkplek onderdrukt. Hypotheses 3 en 5 moeten op basis van dit resultaat worden verworpen voor HNW-werkplek.

Tabel 4 laat een positieve en statistisch significante relatie zien tussen de invoering van $\mathrm{HNW}$-maatregelen en organisatie-identificatie. Hypothese $2 \mathrm{a}$ wordt daarom geaccepteerd: er is een positieve relatie tussen de aanwezigheid van $\mathrm{HNW}$-maatregelen in organisaties en de mate van organisatie-identificatie van de medewerkers. Organisatie-identificatie is bovendien statistisch significant gerelateerd aan kennisdeling (zie tabel 2 en 3). Hypothese $2 b$ wordt geaccepteerd: organisatie-identificatie is positief gerelateerd aan kennisdelen (vgl. Polzer, 2004).

Om hypothese $4 \mathrm{a}$ te testen is een regressieanalyse uitgevoerd van HNW-ICT en HNW-werkplek op autonomie. Tabel 4 laat zien dat HNW-ICT en HNW-werkplek beide een positieve en statistisch significante relatie hebben met autonomie. Hypothese 4a wordt daarom geaccepteerd: er is een positieve relatie tussen de aanwezigheid van HNW-maatregelen in organisaties en de mate van ervaren autonomie van de medewerkers. Tabel 2 en 3 laten zien dat autonomie een statistisch significant effect heeft op kennisdelen. De resultaten ondersteunen hypothese 4b: de mate van ervaren autonomie is positief gerelateerd aan kennisdelen. Tabel 5 laat de resultaten zien van de Sobel-test voor HNW-ICT op kennisdeling. Met identificatie met het bedrijf als verklarende variabele is de teststatistiek gelijk aan 2,10, met een standaard error van ,01. Dit resultaat is statistisch significant $(\mathrm{p}<, 05)$, waardoor de nulhypothese van een directe relatie tussen HNWICT en kennisdelen wordt verworpen. We kunnen concluderen dat de relatie tussen HNW-ICT en kennisdeling wordt verklaard door organisatie-identificatie.

Met autonomie als verklarende variabele is de teststatistiek gelijk aan 2,83, met een standaard error van ,01. Dit resultaat is statistisch significant $(\mathrm{p}<, 01)$, waardoor we kunnen concluderen dat de relatie tussen HNW-ICT en kennisdeling wordt verklaard door autonomie. De relatie wordt gedeeltelijk verklaard door organisatie-identificatie en autonomie, en dus niet volledig, aangezien de relatie tussen HNW-ICT en kennisdelen kleiner wordt, maar wel statistisch significant blijft na de toevoeging van organisatie-identificatie en autonomie als verklarende variabelen.

Concluderend kunnen we stellen dat er een positieve relatie bestaat tussen HNWmaatregelen op het gebied van ICT en kennisdelen in de door ons onderzochte organisatie. De relatie valt gedeeltelijk te verklaren door de mate van organisatieidentificatie en autonomie van de medewerkers. 


\section{Discussie}

Specifiek heeft dit onderzoek zich gericht op de relatie tussen HNW en kennisdelen binnen een grote Nederlandse ICT-dienstverlener waar recentelijk HNWmaatregelen zijn ingevoerd. Wij definiëren HNW als een manier van werken waarbij de kenniswerker op verschillende werklocaties en -ruimtes werkt en gebruikmaakt van ICT-faciliteiten om plaats- en tijdonafhankelijk te werken. De verwachting was dat kennisdelen zou samenhangen met specifieke karakteristieken van HNW: het gebruik van ICT en flexibiliteit in het gebruik van werkplekfaciliteiten. Bovendien werd verwacht dat organisatie-identificatie en autonomie de relatie tussen HNW en kennisdelen grotendeels zouden verklaren.

Dit onderzoek laat zien dat HNW, zoals verwacht, bijdraagt aan kennisdelen, maar alleen wanneer ICT-middelen in ogenschouw worden genomen. Dit betekent dat alleen de mate waarin werknemers gebruik kunnen maken van ICT om plaats- en tijdonafhankelijk te werken, positief gerelateerd is aan de mate van kennisdelen in kennisintensieve organisaties. De aanwezigheid en het gebruik van werkplek-gerelateerde faciliteiten, zoals ontmoetingsruimtes en flexwerkplekken, heeft een kleine maar significante negatieve relatie met de mate van kennisdelen. Deze relatie wordt gemaskeerd door autonomie en organisatie-identificatie. Doordat het gebruik van de mogelijkheden om flexibel te werken een positieve invloed heeft op de ervaren autonomie en organisatie-identificatie van medewerkers, en deze op hun beurt weer een positieve relatie hebben met kennisdelen, wordt het negatieve effect van werkplek-gerelateerde faciliteiten onderdrukt. Een verklaring voor de negatieve relatie is dat de mogelijkheden tot flexibel werken toch vooral individueel worden ingevuld en dat de kans op toevallige ontmoetingen waarbij kennis kan worden gedeeld, kleiner is dan werd voorzien.

Op basis van onze resultaten concluderen wij dat kennisintensieve organisaties baat kunnen hebben bij het invoeren van ICT-faciliteiten om plaats- en tijdonafhankelijk te werken. Onze resultaten laten zien dat ICT, zoals videoconferentie, kan leiden tot een toename in kennisdelen. Dit is een belangrijke bevinding, omdat een betere benutting van kennis kan helpen bij het realiseren van de organisatiedoelen en kan leiden tot een voordeel ten opzichte van andere bedrijven nu en in de toekomst (vgl. Argote \& Ingram, 2000; Huang, 2009; Yuan, 2010). Om een verklaring te vinden voor de mogelijke relatie tussen HNW en kennisdelen heeft deze studie gekeken naar de rol van organisatie-identificatie en autonomie van werknemers. Uit de resultaten is gebleken dat de relatie tussen ICT-faciliteiten om plaats- en tijdonafhankelijk te werken en kennisdelen deels wordt verklaard door organisatie-identificatie en autonomie.

Een mogelijke verklaring voor de gevonden relatie tussen HNW en organisatieidentificatie is dat de toegenomen ICT-faciliteiten informele en elektronische communicatie stimuleren (zie ook Wiesenfeld et al., 1999). De toename aan informele en elektronische communicatie helpt werknemers een actieve rol te spelen in het creëren en delen van de organisatie-identiteit. De door ons gevonden toename van organisatie-identificatie kan mogelijk ook worden veroorzaakt door het feit dat ICT en werkplek-gerelateerde faciliteiten werknemers helpen om op verschillende plekken in de organisatie te kunnen werken en niet alleen op de eigen 
werkplek. Werknemers hebben nu de mogelijkheid om meer afdelingen en collega's te leren kennen en kunnen daarom een beter begrip creëren van de organisatie als geheel. Polzer (2004) stelt bovendien dat werknemers die zich meer identificeren met het bedrijf, meer kennis delen.

De verklaring voor de door ons gevonden relatie tussen HNW en ervaren autonomie lijkt vooral te liggen in het feit dat medewerkers door de invoering van ICT en werkplek-gerelateerde faciliteiten meer dan voorheen de mogelijkheid krijgen om zelf te bepalen waar, wanneer en met welke middelen zij werken (Elsbach, 2003; Standen, 2000).

\section{Beperkingen van de studie en richting voor vervolgonderzoek}

De gepercipieerde kwaliteit van kennisdelen, zoals door ons gemeten, is geen weergave van de feitelijke kwaliteit en kwantiteit van het kennisdelen binnen de organisatie. De vraag is of medewerkers een goede inschatting kunnen maken van de mate waarin zij kennisdelen. Het onderzoek is bovendien uitgevoerd onder werknemers van een IT-dienstverlener. Bij dit bedrijf werken voor het merendeel mannen met een verhoogde interesse in ICT. Het lijkt ons aannemelijk dat de mate waarin volgens de principes van HNW wordt gewerkt, sterk afhankelijk is van functietype en het type werkzaamheden. Een herhaling van dit onderzoek bij een ander bedrijf zou kunnen leiden tot andere resultaten.

Tevens moeten we benoemen dat dit artikel gericht is op twee deelaspecten van HNW, namelijk ICT en werkplek-gerelateerde faciliteiten. Het belang van een goede managementcultuur en een juiste implementatiestrategie komt steeds vaker naar voren (Van den Brink \& Gompers, 2011). Deze deelaspecten kunnen zeer bepalend zijn voor de daadwerkelijke effecten van HNW op bedrijfsdoelstellingen als kennisproductie en innovatie.

Autonomie is in deze studie geoperationaliseerd als werkindeling-autonomie. Uit onderzoek van Breaugh (1985) en Evans en Fischer (1992) blijkt dat er naast werkindeling-autonomie nog twee andere dimensies van autonomie bestaan: werkmethode-autonomie en werkcriteria-autonomie. In een vervolgonderzoek zou het verstandig zijn om deze dimensies mee te nemen, zodat er een vollediger beeld van de rol van autonomie op de relatie tussen HNW en kennisdelen in kennisintensieve organisaties kan worden geschetst.

Een andere beperking van de huidige studie is het gebruik van digitale vragenlijsten voor het verzamelen van de data. Ondanks de vele voordelen van de digitale vragenlijst, zoals het grote bereik, het ontbreken van interviewer-bias en de mogelijkheid om conditionele vragen te stellen, zijn er ook nadelen verbonden aan het afnemen van een digitale vragenlijst. Het is bijvoorbeeld niet duidelijk wie de vragenlijst invult (Topp \& Pawloski, 2002), wat respondenten doen tijdens het invullen, en in welke mentale staat zij zijn (Stanton, 1998). Een trage internetverbinding kan bijvoorbeeld de gemoedstoestand van de respondent op een negatieve manier beïnvloeden. Dit kan zijn weerslag hebben op de resultaten. Er bestaan ook praktische nadelen: zo bestaat het gevaar dat de computer vastloopt of de internetverbinding uitvalt en de respondent noodgedwongen stopt met het invullen van de vragenlijst. 
De cross-sectionele opzet van dit onderzoek kan ook worden genoemd als beperking. Het is dan ook niet mogelijk om een conclusie te trekken over de richting van de causaliteit. Een studie met een longitudinale of causale opzet kan hier uitkomst bieden. Een interessante vraag is of ICT leidt tot meer kennisdelen of dat werknemers die graag kennis willen delen, sneller gebruikmaken van de beschikbare ICT-faciliteiten die onder de noemer van HNW worden aangeboden.

Deze studie laat zien dat ICT kan bijdragen aan kennisdelen. Deze studie laat echter niet zien welke specifieke ICT-faciliteiten verantwoordelijk waren voor de toename in kennisdelen. Welk effect heeft bijvoorbeeld het gebruik van digitale agenda's, bedrijfschats of interne zoeksystemen op kennisdelen of andere interessante uitkomsten? Een interessante richting voor vervolgonderzoek is dan ook een studie naar de effecten van specifieke ICT-maatregelen op kennisdelen. Dit kan resulteren in een meer compleet overzicht van alle relevante aspecten van HNW.

Een andere richting voor vervolg is een studie naar overige factoren die de relatie tussen HNW en kennisdelen beïnvloeden, zoals leiderschapsstijl. De rol van managers en leidinggevenden wordt in de literatuur over telewerken vaak genoemd. Kurland en Cooper (2002) stellen dat een inadequate training van leidinggevenden over het begeleiden van telewerkers kan leiden tot mispercepties en miscommunicaties tussen leidinggevenden en medewerkers. Wil telewerken succesvol zijn, dan moeten leidinggevenden leren om effectieve mentoren te zijn op afstand. Bailey en Kurland (2002), Baan (2006) en Peters, Bleijenbergh en Oldenkamp (2009) benadrukten dat managers hun welwillendheid ten opzichte van telewerken duidelijk moeten tonen om de implementatie van telewerken te laten slagen. Mogelijk vrezen managers en leidinggevenden voor het gebrek aan controle op telewerkers. Het is daarom van belang om managers en leidinggevenden het nut en de voordelen van telewerken te laten inzien voordat telewerken wordt geïmplementeerd (Bailey \& Kurland, 2002). Aangezien de rol van managers en leidinggevenden van groot belang is bij telewerken, kunnen we verwachten dat dit ook geldt voor HNW. Vervolgonderzoek kan ons inzicht geven in het effect van de rol van managers en manieren om HNW via leidinggeven effectief te laten zijn.

Niet alleen management kan HNW doen slagen of mislukken, medewerkers zelf hebben hier ook een belangrijk aandeel in. Negatieve percepties van werknemers kunnen de implementatie van HNW doen mislukken. Negatieve percepties kunnen ontstaan als werknemers zich zorgen maken over de mogelijke negatieve invloed die plaats- en tijdonafhankelijk werken kan hebben op hun carrièremogelijkheden en hun zichtbaarheid in de organisatie (Harris, 2003; Crandall \& Gao, 2005). Kurland en Cooper (2002) stellen dat het bij telewerken belangrijk is om in te spelen op deze zorgen door als organisatie duidelijk te communiceren dat afwezigheid op kantoor niet zal leiden tot een slechtere beoordeling of minder ontwikkelmogelijkheden. Vervolgonderzoek kan uitwijzen of deze managementinterventie ook werkt bij HNW.

Nog een richting voor vervolg is de rol van individuele verschillen. Individuele verschillen kunnen een rol spelen bij het duiden van de effecten van HNW en het voorspellen van de effectiviteit in de praktijk. Baruch (2000) laat zien dat zelfdis- 
cipline en intrinsieke motivatie van groot belang zijn voor effectief plaats- en tijdonafhankelijk werken. Ook individuele disposities en vaardigheden lijken de acceptatie van telewerken te bepalen. Mensen met een hoge behoefte aan autonomie blijken positief te reageren op telewerken en waarderen de voordelen van telewerken meer dan mensen met een lage autonomie. Het is interessant om te onderzoeken in welke mate deze attributen bijdragen aan het succes van HNW. Dit kan helpen om trainingen te ontwikkelen en te identificeren wie in een organisatie het meeste baat hebben bij HNW.

\section{Literatuur}

ANP (2011, 9 maart). Vrouwen vinden thuiswerken lastiger. NU Zakelijk. Gedownload op 27 juli 2011 van www.nuzakelijk.nl/werk/2463875/vrouwen-vinden-thuiswerken-lastiger.html.

Argote, L. \& Ingram, P. (2000). Knowledge transfer: A basis for competitive advantage in firms. Organizational Behavior and Human Decision Processes, 82(1), 150-169.

Ashforth, B.E. \& Mael, F. (1989). Social identity theory and the organization. The Academy of Management Review, 14(1), 20-39.

Baan, A. (2006). Virtueel werken. Het kan! Samenwerken in een veranderende wereld. Leren in Organisaties, 10, 30-32.

Bailey, D.E. \& Kurland, N.B. (2002). A review of telework research: Findings, new directions, and lessons for the study of modern work. Journal of Organizational Behavior, 23, 383-400.

Baron, R.M. \& Kenny, D.A. (1986). The moderator-mediator variable distinction in social psychological research: Conceptual, strategic, and statistical considerations. Journal of Personality and Social Psychology, 51(6), 1173-1182.

Bartol, K.M. \& Srivastava, A. (2002). Encouraging knowledge sharing: The role of organizational reward systems. Journal of Leadership and Organization Study, 9(1), 64-76.

Baruch, Y. (2000). Teleworking: benefits and pitfalls as perceived by professionals and managers. New Technology, Work and Employment, 15(1), 34-49.

Bijl, D. (2009). Aan de slag met het nieuwe werken. Zeewolde: Par CC.

Blok, M., Groenesteijn, L., Berg, C. van den \& Vink, P. (2011). New ways of working: A proposed framework and literature review. In M.M. Robertson (ed.), Ergonomics and Health Aspects (pp. 3-12), HCII, LNCS 6779.

Breaugh, J.A. (1985). The measurement of work autonomy. Human Relations, 38(6), 551-570.

Brewer, M.B. (1979). In-group bias in the minimal intergroup situation: A cognitive-motivational analysis. Psychological Bulletin, 86, 307-324.

Brewer, M.B. (1981). Ethnocentrism and its role in interpersonal trust. In M.B. Brewer \& B.E. Collins (eds.), Scientific inquiry and the social sciences. New York: Jossey-Bass.

Brink, P. van den \& Gompers, R. (2011). De kunst van Het Nieuwe Werken. Uitgeverij Tiem.

Butler, E.S., Aasheim, C. \& Williams, S. (2007). Does telecommuting improve productivity? Communications of the ACM, 50(4), 101-103.

Cabrera, Á., Collins, W.C. \& Selgado, J.F. (2006). Determinants of individual engagement in knowledge sharing. International Journal of Human Resource Management, 17(2), 245-264. 
Coevert, A. (2012, 5 september). Nederland blijft stijgen op ranglijst meest concurrerende economieën. NRC.nl. Gedownload op 4 december 2012 van www.nrc.nl/nieuws/ 2012/09/05/nederland-blijft-stijgen-op-ranglijst-meest-concurrerende-economieen/.

Dutton, J.E., Dukerich, J.M. \& Harquail, C.V. (1994). Organizational images and member identification. Administrative Science Quarterly, 39, 239-263.

Elsbach, K.D. (2003). Relating physical environment to self-categorizations: Identity threat and affirmation in a non-territorial office space. Administrative Science Quarterly, 48(4), 622-654.

Evans, B.K. \& Fischer, D.G. (1992). A hierarchical model of participatory decision-making, job autonomy, and perceived control. Human Relations, 45, 1169-1189.

Fiol, C.M. \& O'Connor, E.J. (2005). Identification in face-to-face, hybrid, and pure virtual teams: Untangling the contradictions. Organization Science, 16(1), 19-32.

Gajendran, R.S. \& Harrison, D.A. (2007). The good, the bad, and the unknown about telecom-muting: Meta-analysis of psychological mediators and individual consequences. Journal of Applied Psychology, 92(6), 1524-1541.

Golden, T.D. (2006). Avoiding depletion in virtual work: Telework and the intervening impact of work exhaustion on commitment and turnover intentions. Journal of Vocational Behavior, 69, 176-187.

Gorton, I. \& Motwani, S. (1996). Issues in co-operative software engineering using globally distributed teams. Information and Software Technology, 38, 647-655.

Griffin, M.A., Neal, A. \& Parker, S.K. (2007). A new model of work role performance: Positive behavior in uncertain and interdependent contexts. Academy of Management Journal, 50(2), 327-347.

Gupta, A., Mattarelli, E., Seshasai, S. \&Broschak, J. (2009). Use of collaborative technologies and knowledge sharing in co-located and distributed teams : Towards the 24-h knowledge factory. Journal of Strategic Information Systems, 18, 147-161.

Habets, M. (2009, 24 november). Voor- en nadelen van het nieuwe werken. Management Team. Gedownload op 28 april 2011 van www.mt.nl/90/12466/management/voor-ennadelen-van-het-nieuwe-werken.html.

Hackman, R. \& Oldham, G.R. (1975). Development of the Job Diagnostic Survey. Journal of Applied Psychology, 60(2), 159-170.

Harpaz, I. (2002). Advantages and disadvantages of telecommuting for the individual, organization and society. Work Study, 51(2), 74-80.

Harris, L. (2003). Home-based teleworking and the employment relationship. Personnel Review, 32(4), 422-437.

Hendriks, P. (1999). Why share knowledge? The influence of ICT on the motivation for knowledge sharing. Knowledge and Process Management, 6(2), 91-100.

Hinds, P.J. \& Bailey, D.E. (2003). Out of sight, out of sync: Understanding conflict in distributed teams. Organization Science, 14(6), 615-632.

Hobbs, D. \& Armstrong, J. (1998). An experimental study of social and psychological aspects of teleworking. Facilities, 16(12), 366-371.

Huang, C. (2009). Knowledge sharing and group cohesiveness on performance: An empirical study of technology R\&D teams in Taiwan. Technovation, 29, 786-797.

Illegems, V. \& Verbeke, A. (2004). Telework: What does it mean for management? Long Range Planning, 37, 319-334.

Kamerade, D. \& Burchell, B. (2004). Teleworking and participatory capital: Is teleworking an isolating or a community-friendly form of work? European Sociological Review, 20(4), 345-361. 
Kiesler, S. \& Cummings, J.N. (2002). What do we know about proximity and distance in work groups? A legacy of research. In P. J. Hinds \& S. Kiesler (eds.), Distributed work (pp. 57-80). Cambridge, MA: Massachusetts Institute of Technology.

Kleij, R. van der \& Schraagen, J.M.C. (2006). Enabling team decision making. In C. Bowers, E. Salas \& F. Jentsch (eds.), Creating high-tech teams: Practical guidance on work performance and technology (pp. 35-50). Washington, DC: APA Books.

Kleij, R. van der, Schraagen, J.M.C., Dreu, C.K.W. de \& Werkhoven, P. (2009). How conversations change over time in face-to-face and video-mediated communication. Small Group Research, 40, 355-381. DOI: 10.1177/1046496409333724

Kleij, R. van der, Six, C. \& Veldhuis, G.J. (2008). Kennismanagement bij Defensie: Naar een integrale aanpak die stuurt op organisatieprocessen, mensen, en techniek. TNO-DV 2008 IN236.

Kraut, R.E., Fussell, S.R., Brennan, S.E. \& Siegel, J. (2002). Understanding effects of proximity on collaboration: Implications for technologies to support remote collaborative work .In P.J. Hinds \& S. Kiesler (eds.), Distributed work (pp.137-162). Cambridge, MA: Massachusetts Institute of Technology.

Kurland, N.B. \& Cooper, C.D. (2002). Manager control and employee isolation in telecommuting environments. Journal of High Technology Management Research, 13, 107-126.

Lammers, J. (1995). Grootschalig veldonderzoek: Inleiding in de data-analyse. Houten: Coutinho.

Langfred, C.W. (2004). Too much of a good thing? Negative effects of high trust and individual autonomy in self-managing teams. Academy of Management Journal, 47(3), 385-399.

Loon, M. van (2011, 11 mei). Man vindt nieuwe werken belangrijker. NU Zakelijk. Gedownload op 27 juli 2011 van www.nuzakelijk.nl/werk/2512681/man-vindt-nieuwe-werken-belangrijker.html.

Mael, F. \& Ashforth, B.E. (1992). Alumni and their alma mater: A partial test of the reformulated model of organizational identification. Journal of Organizational Behavior, 13(2), 103-123.

Mael, F. \& Ashforth, B.E. (1995). Loyal from day one: Biodata, organizational identification, and turnover among newcomers. Personnel Psychology, 48, 309-333.

Morgeson, F.P. \& Humphrey, S.E. (2006). The Work Design Questionnaire (WDQ): Developing and validating a comprehensive measure for assessing job design and the nature of work. Journal of Applied Psychology, 91(6), 1321-1339.

Orton, J.D. \& Weick, K.E. (1990). Loosely coupled systems: A reconceptualization. Academy of Management Review, 15(2), 203-223.

Peters, P., Bleijenbergh, I. \& Oldenkamp, E. (2009). The telework adoption process in a Dutch and French subsidiary of the same ICT-multinational: How national culture and management principles affects the success of telework programs. Journal of eWorking, 3(1), 1-16.

Polzer, J.T. (2004). How subgroup interest and reputations moderate the effect of organizational identification on cooperation. Journal of Management, 30(1), 71-96.

Quinn, J.B., Anderson, P. \& Finkelstein, S. (1996). Leveraging intellect. Academy of Management Executive, 10, 7-27.

Richardson, J. (2010). Managing flexworkers: holding on and letting go. Journal of Management Development, 29(2), 137-147.

Rico, R. \& Cohen, S. (2005). Effects of task interdependence and type of communication on performance in virtual teams. Journal of Managerial Psychology, 20(3), 261-274.

Shin, B., Sheng, O.R.L. \& Higa, K. (2000). Telework: Existing research and future directions. Journal of Organizational Computing and Electronic Commerce, 10(2), 85-101. 
Spek, R. van der \& Spijkervet, A. (1996). Kennismanagement: Intelligent omgaan met kennis. Utrecht: Kenniscentrum CIBIT.

Standen, P. (2000). The home/work interface. In K. Daniels, D.A. Lamond \& P. Standen (eds.), Managing telework: Perspectives from human resource management and work psychology (pp. 83-92). London: Business Press.

Stanton, J.M. (1998). An empirical assessment of data collection using the Internet. Personnel Psychology, 51, 709-726.

Topp, N.W. \& Pawloski, B. (2002) Online data collection. Journal of Science Education and Technology, 11, 173-178.

Tsai, W. (2002). Social structure of 'coopetition' within a multiunit organization: Coordination, competition, and intraorganizational knowledge sharing. Organization Science, 13(2), 179-190.

Turner, A.N. \& Lawrence, P.R. (1965). Industrial jobs and the worker: An investigation of response to task attributes. Boston: Harvard University Graduate School of Business Administration.

Usoro, A., Sharratt, M.W., Tsui, E. \& Shekhar, S. (2007). Trust as an antecedent to knowledge sharing in virtual communities of practice. Knowledge Management Research and Practice, 5, 199-212.

Venkatesch, V. \& Speier, C. (2000). Creating an effective training environment for enhancing telework. International Journal of Human-Computer Studies, 52, 991-1005.

Vink, P. (2009). Aangetoonde effecten van het kantoorinterieur. Alphen aan den Rijn: Kluwer.

Vink, P., Blok, M. \& Groenesteijn, L. (2011). Onderzoeksgegevens van belang voor het nieuwe werken. In P. van den Brink \& R. Gompers (red.), De kunst van Het Nieuwe Werken. Uitgeverij TIEM. www.dekunstvanhetnieuwewerken.nl.

Vries, H. de \& Wijers, T. (1998). Zicht op telewerken: Een studie naar de stand van zaken in de kennis over telewerken en de impact op de beleidsterreinen van SZW. Den Haag: Ministerie van SZW.

Weggeman, M.C.D.P. (1997). Kennismanagement: Inleiding en besturing van kennisintensieve organisaties. Schiedam: Scriptum.

Wermenbol, G. (2008, 6 juli). Het Nieuwe Werken vraagt om een Mentaliteitsverandering. Volkskrant Banen. Gedownload op 23 mei, 2011van www.vkbanen.nl/banen/artikel/ Het-nieuwe-werken-vraagt-om-een-mentaliteitsverandering/65649.html.

Wiesenfeld, B.M., Raghuram, S. \& Garud, R. (1999). Communication patterns and determinants of organizational identification in a virtual organization. Organization Science, 10(6), 777-790.

Wiesenfeld, B.M., Raghuram, S. \& Garud, R. (2001). Organizational identification among virtual workers: The role of need for affiliation and perceived work-based social support. Journal of Management, 27, 213-229.

Yuan, Y.C. (2010). Review of the book Managing knowledge networks, by J.D. Johnson. Journal of Communication, 60, E13-E15. 